\title{
UMA NOVA VARIEDADE DE Vriesea atra Mez
}

Gustavo Martinelli *

\section{INTRODUÇÃO}

Há seis anos vem sendo realizado o levantamento da vegetação do Morro do Cuca, em Petrópolis, Estado do Rio de Janeiro, onde ocorre uma interessante flora montana. O local formado por elevações graníticas com alturas superiores a $1200 \mathrm{~m} / \mathrm{s} . \mathrm{m}$., tem seu ponto de maior altitude situado a $1880 \mathrm{~m} / \mathrm{s} . \mathrm{m}$., sendo considerada por diversos autores como pertencente ao sistema orográfico da Serra dos Orgãos.

Em recente excursão ao local, encontraram-se exemplares de Vriesea atra Mez cujas folhas diferiam daquelas da espécie típica, que considerou-se uma nova variedade para a Ciência.

Vriesea atra Mez var. variegata Martinelli \& Leme n. var.

"Differt var. typica foliis variegatis".

HOLOTYPUS: RB nọ 207317. Leg: G. Martinelli nọ 7793 \&Leme, 29-XI-1981.

DISTRIBUIÇÃO GEOGRÁfICA: Brasil, Estado do Rio de Janeiro, Município de Petrópolis, Vale das Videiras, Morro do Cuca, $1700 \mathrm{~m} / \mathrm{s} . \mathrm{m}$.

HABITAT: rupicola, heliófila, na vertente de rocha nua do lado Norte, associada a Vriesea imperialis Carr., crescendo em touceiras, $1700 \mathrm{~m} / \mathrm{s} . \mathrm{m}$.

OBSERVAÇÕES: Tanto a espécie típica como esta nova variedade possuem flores de hábito noturno. Outro exemplar da variedade em questão está sendo cultivado, permanecendo com as mesmas caracter ísticas da planta quando coletada.

\section{REFERENCIA BIBLIOGRAFICA}

Mez, C. in Martius, FI. Bras. 3 (3): 543, pl. 101, 1894.

* Pesquisador do Jardim Botânico do Rio de Janeiro Bolsista do CNPq 


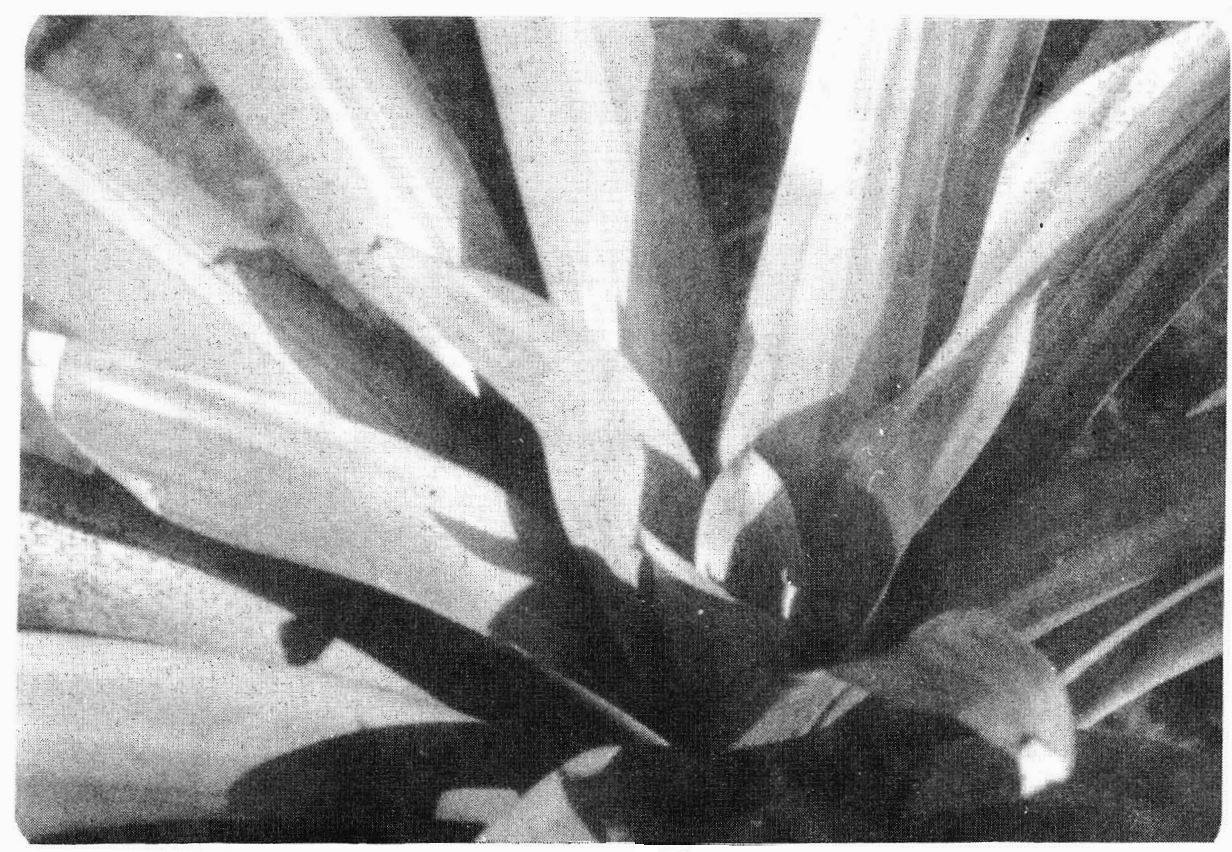

Foto 1 - Detalhe das folhas de $V$. atra var. variegata.

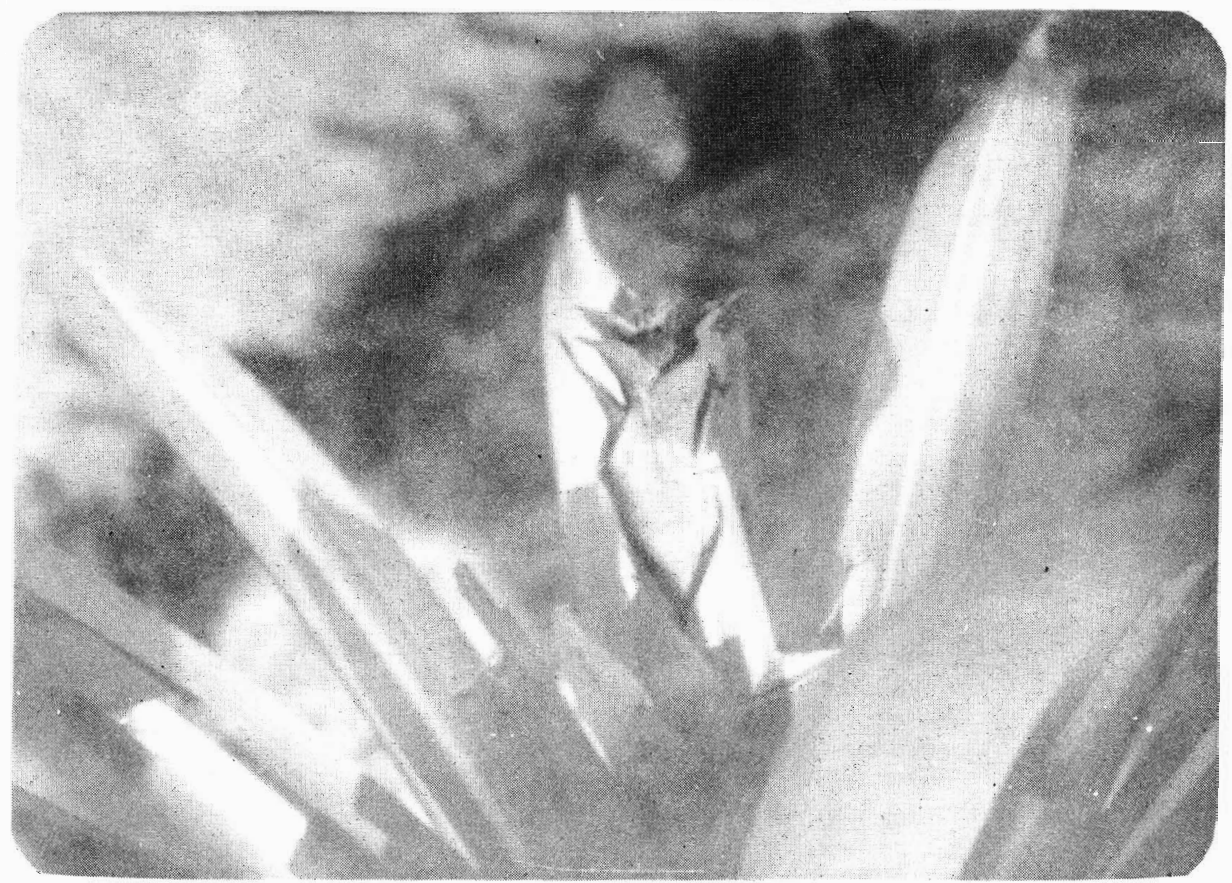

Foto 2 - Vriesea atra var, variegata com estágio inicial da inflorescência, no habitat. 